Boże oraz potrafił żyć z Nim we wspólnocie, w wierze i posłuszeństwie. Autor książki, będąc jezuita, na koniec omówił wychowanie religijne na przykładzie pedagogii ignacjańskiej, która ma swoje źródło w dynamice i ćwiczeniach duchowych proponowanych przez Ignacego Loyolę. Ważne jest stwierdzenie, że istotną rolę $\mathrm{w}$ pedagogii tej spełniają doświadczenia człowieka, dzięki którym stawia się pytania prowokujące do myślenia, a więc kształtuje się inteligencję oraz wyobraźnię i uczucia. Dlatego ważne są cztery elementy pedagogii ignacjańskiej: doświadczenie, refleksja, działanie i ocena.

Reasumując, można powiedzieć, że omawiana publikacja ks. prof. Z. Marka: Religia pomoc czy zagrożenie dla edukacji?, pozwala na dostrzeżenie istoty religii $\mathrm{w}$ procesie edukacyjnym oraz wskazuje punkty styczne łączące edukację i religię. Lektura tej książki poszerza perspektywy osobistego patrzenia na świat. Daje możliwości lepszego odniesienia się do religii i jej roli w edukacji. Książka wpisuje się znakomicie we współczesne postrzeganie świata i edukacji nowych pokoleń, które może nie zawsze wnikają w teologiczną i pedagogiczną głębię edukacji religijnej, ale z pewnością mogą z niej korzystać, ukierunkowując swoje myśli na to, co tak naprawdę nadaje sens życiu. Pozycja ta pojawia się we właściwym czasie i stanowi istotny wkład w myśl społeczną w okresie szybkich przemian kulturowych i religijnych. Jej treści posiadają bardzo czytelny przekaz istotnych problemów, ujawniających się obecnie w społeczeństwie laickim i Kościele. Książka ta z pewnością zainteresuje nauczycieli akademickich oraz studentów katechetyki, teologii, a przede wszystkim pedagogów i nauczycieli religii.

Mirosław Stanisław Wierzbicki*

\title{
Marek Jeziorański, Bt. Jana Pawła II koncepcja wychowania mat- żonków, Wydawnictwo KUL, Lublin 2013, ss. 291
}

DOI: http://dx.doi.org/I0.12775/PCh.2014.034

Niebawem minie dziesięć lat od śmierci Jana Pawła II, a jego nauczanie jest cały czas na nowo zgłębiane. Wybór recenzowanej książki jest więc

* Ks. dr Mirosław Stanisław Wierzbicki SDB pracuje w Wydziale Nauk o Wychowaniu Papieskiego Uniwersytetu Salezjańskiego w Rzymie w Instytucie Katechetyki na stanowisku adiunkta w katedrze Pedagogiki Religii. 
dla mnie związany z chęcią odkrywania tego nauczania w odniesieniu do rodziny i małżeństwa, a także próbą zachęcenia czytelników do refleksji nad tymi rzeczywistościami w świetle analiz, jakie podjął Jan Paweł II, a zebrał i uporządkował ks. dr Marek Jeziorański. Autor niniejszej książki jest nauczycielem akademickim Katolickiego Uniwersytetu Lubelskiego, gdzie w 2012 roku ukończył studia doktoranckie w Instytucie Pedagogiki na Wydziale Nauk Społecznych. Zainteresowania autora koncentrują się wokół nauczania Jana Pawła II, nurtów filozofii, pedagogiki i problematyki rodzinnej, na co wskazują liczne artykuły oraz niniejsza publikacja.

Na wstępie zaznaczmy, że autor dostrzega potrzebę zagłębienia się w nauczanie Jana Pawła II na temat wychowania małżeństwa i rodziny, aby w ten sposób służyć pomocą współczesnym małżeństwom i rodzinom. Wyciagając wnioski z papieskiego nauczania, Marek Jeziorański uważa, że wychowanie małżeństw jest konieczne w dobie coraz większej ilości rozwodów i nieformalnych związków. Już w pierwszych słowach stwierdza:

Błogosławiony Jan Paweł II w swoich przemówieniach i pismach dużo miejsca poświęcił zagadnieniu małżeństwa i rodziny. Często podkreślał, że wspieranie tej wspólnoty życia jest zadaniem priorytetowym zarówno dla Kościoła, jak i dla społeczeństwa. Dobrze rozwijająca się rodzina jest bowiem najtrwalszym fundamentem rozwoju wszelkich wartości, służących dobru człowieka i całych społeczności, aż po wymiar globalny (s. 13).

Jak zatem układać życie małżeńskie i rodzinne, aby było szczęśliwe? Jak stworzyć związek trwały? Jak pomóc małżeństwom i rodzinom, aby przetrwały chwile trudne? Na te i wiele innych pytań próbuje odpowiedzieć niniejsza publikacja, która skierowana jest do każdego, kto poszukuje prawdy na temat małżeństwa i rodziny, a dodatkowo chce choć trochę poznać naukę św. Jana Pawła II.

Marek Jeziorański wnikliwie przedstawia w swojej publikacji zagadnienie wychowania małżonków, które znajduje swoje umiejscowienie w pedagogice rodziny. Autor dokonuje analizy wielu dokumentów pracy naukowej Karola Wojtyły, później papieża i rzeczowo wprowadza w jego personalistyczną koncepcję wychowania małżonków. Czytelnik może zapoznać się ze źródłami inspiracji naukowej Papieża oraz jego osobistymi doświadczeniami, przybliżającymi mu zagadnienie relacji małżeńskich. Wyjaśnione zostają również występujące w książce podstawowe terminy, którymi posługiwał się Papież, a także rozumienie przez niego rozwoju wspólnoty małżonków. Na 
uwagę zasługuje też rozdział mówiący o aksjologii wychowania małżonków. Jest on w mojej opinii szczególnie ważny i warty podjęcia głębszej refleksji. Jaką wartość ma małżeństwo? Jakie miejsce zajmuje w środowisku społecznym? Bez jakich wartości nie ma ono szans przetrwania i do jakich zagrożeń dochodzi wskutek odrzucenia wartości wspólnoty małżeńskiej i rodziny? $\mathrm{Na}$ te $\mathrm{i}$ inne pytania z zakresu aksjologii, odnoszące się do małżeństwa i rodziny, stara się odpowiedzieć autor publikacji, zgłębiając nauczanie Jana Pawła II. Myślę, że na uwagę zasługuje również zagadnienie metodyki wychowania małżonków, które zostało opracowane na podstawie papieskiego nauczania. Obejmuje ono kwestie: środków, zasad i metod wychowywania. Zostało doskonale przemyślane przez autora książki i stanowi wartościową wskazówkę dla osób chcących zakładać rodzinę, dla tych, którzy już ją założyli, jak również dla osób pracujących z rodzinami.

Marek Jeziorański dzieli tekst pracy na rozdziały, podrozdziały i podpodrozdziały, co pozwala czytelnikowi na wnikliwe zgłębianie tematu, logiczne łączenie przekazywanych treści i podejmowanie refleksji nad nimi. Sądzę, że złożony układ treści podejmowanych w publikacji i forma ich zapisu zachęcają czytelnika do powtórnego przeanalizowania interesujących go zagadnień i problemów. Mając na uwadze dobór literatury, muszę podkreślić, że autor korzystał z różnorodnych materiałów, co pozwoliło mu na wnikliwe przeanalizowanie koncepcji Jana Pawła II, dotyczącej wychowania małżonków, a tym samym na wskazanie na wagę podjętego zagadnienia. W bibliografii znajdują się liczne dokumenty ogólnokościelne, publikacje Karola Wojtyły, przemówienia, rozważania, orędzia i homilie papieskie, a także bardzo liczne dzieła naukowe innych autorów poruszające problematykę wychowania, rodziny, małżeństwa, sytuujące się w obszarach pedagogiki, psychologii oraz socjologii. Z analizy przypisów i bibliografii wynika, że autor korzystał również z wielu teologicznych prac naukowych. Książkę Marka Jeziorańskiego charakteryzuje szeroka perspektywa badawcza oraz naukowa precyzja, gdyż dokonał on analizy bardzo obszernego nauczania papieskiego, wskazując na to, jaki wzorzec życia małżeńskiego zaproponował Jan Paweł II, a także o jakim wychowaniu w nim mówił.

Sądzę, że walorem recenzowanej pracy jest także próba polemiki z osobami reprezentującymi inne podejścia do kwestii małżeństwa i rodziny. Autor omówił odmienne od papieskiego rozumienie zagadnienia wychowania małżonków, co pozwala czytelnikowi na samodzielną refleksję i analizę tematu. Przemyślane jest również podsumowanie konkretnego tematu w każdym z rozdziałów i logiczne nawiązanie do kolejno omawianego. W książce 
Marka Jeziorańskiego znajduje się wiele cytatów i odniesień do nauczania Jana Pawła II, które obrazują formułowane wnioski, ale również stają się zachętą do sięgnięcia po oryginalne zbiory wypowiedzi Jana Pawła II.

Celem, jaki autor stawia książce, jest ukazanie specyfiki nauczania Jana Pawła II na temat wychowania małżonków. Uważam, że bardzo dobrze sobie z tym radzi, powołując się na zbiór obszernych badań naukowych Papieża. Publikacja składa się z pięciu logicznie powiązanych ze sobą rozdziałów, którym postawiono kolejno cele szczegółowe, takie jak poznanie specyfiki rzeczywistości wychowania małżonków, usystematyzowanie wiedzy w badanym temacie i ukazanie koncepcji Papieża oraz wskazanie na jej aktualność i możliwość jej realizacji we współczesnych okolicznościach życia rodzinnego i małżeńskiego. Myślę, że autor, realizując w książce powyższe cele, doskonale trafia zarówno do osób młodych, jak i starszych. Małżeństwo i rodzina od zawsze zmagały się z problemami wzajemnych więzi, szacunku, wychowania, a tym samym zadawały sobie pytania o kształtowanie siebie i budowanie pełnych miłości i dobra wzajemnych relacji. Myślę, że książka ta jest wartościową odpowiedzią na współczesne poszukiwanie prawdy o rodzinie oraz pytania dotyczące jej istoty.

Czytelnik niniejszej publikacji może odnieść niekiedy wrażenie, że autor podejmuje kilkakrotnie ten sam temat i że wraca do poruszonych wcześniej zagadnień. Takowe działania są jednak w pełni uzasadnione, gdyż pozwalają na odkrywanie danej problematyki z wielu stron, co z kolei prowadzi do lepszego zrozumienia omawianych treści. Czytając recenzowaną książkę, można dostrzec, że autor doskonale orientuje się w omawianym temacie i pragnie wyczerpująco przedstawić każdemu czytającemu nauczanie papieskie, dotyczące wychowania małżonków. Publikacja w niektórych momentach zaskakuje i odkrywa przed czytelnikiem nowe spojrzenie na osobę, relacje międzyludzkie oraz źródła szczęścia w życiu małżeńsko-rodzinnym. Myślę, że zgłębiając treści książki, można podjąć wiele refleksji nad swoim życiem, nad jego przeżywaniem i sensem. Pokuszę się o stwierdzenie, że nauczanie papieskie przybliżone w niniejszej publikacji niekiedy może zawstydzić i pobudzić do odmiennego spojrzenia na otaczające nas osoby. Myśl personalistyczna Jana Pawła II przedstawiona przez Marka Jeziorańskiego wydaje się odpowiedzią na dzisiejsze konsumpcyjne, pełne przepychu i wygód życie. Co więcej, rzuca światło na problemy społeczeństwa, a także wychowania dzieci i młodzieży. Autor, pisząc o wkładzie naukowym Papieża w refleksję nad życiem małżeńskim i rodzinnym, doskonale dostrzega potrzebę nieustannego pochylania się nad owym nauczaniem i odkrywania cennych wskazówek, istotnych dla życia współczesnych małżonków. 
Publikacja wydobywa ogromnie potrzebne dziś informacje, dotyczące życia małżeńskiego, jego dynamiki i przemian w nim zachodzących. Uważam, że na podstawie dokonanych w książce analiz mogą wyłonić się kolejne, nowe obszary badań nad wychowaniem małżonków, stylem ich życia i możliwościami kształtowania postaw.

Książkę Bt. Jana Pawła II koncepcja wychowania matżonków charakteryzuje wieloaspektowe i wnikliwe podejście do osoby ludzkiej, a przede wszystkim zakładanego przez nią małżeństwa, co pozwala każdemu czytelnikowi na pogłębienie wiedzy w danym obszarze, a także refleksję nad wdrożeniem nauczania papieskiego we własne życie. Myślę, że cenne jest w książce podjęcie problemów społecznych, rodzinnych i małżeńskich, wynikających ze źle pojmowanych miłości i szczęścia. Znacznym walorem recenzowanej publikacji są również wszelkie zawarte w niej przemyślenia, dotyczące koncepcji wychowania małżonków, które zachęcają czytelnika do dyskusji nad jej aspektami filozoficznymi, psychologicznymi, pedagogicznymi oraz moralno-duchowymi. Czytając tę publikację, na pewno dostrzeżemy wiele rad i wskazówek, z którymi oczywiście nie musimy się zgadzać, jednakże zawsze możemy poddać je głębszej refleksji, a może nawet poddać badaniom i sprawdzić, czy zastosowanie ich w praktyce ma jakieś przełożenie na życie innych i nasze.

Uważam, że autor w bardzo przystępny sposób przedstawia nauczanie papieskie i daje odpowiedź na pytanie, jak wychowywać miłość małżeńską, a także jak sprostać współczesnym wyzwaniom w obszarze małżeństwa i rodziny. Książkę poleciłabym każdemu, kto interesuje się problematyką małżeńską, kto szuka miłości, radości i spełnienia w rodzinie, a także otaczającym go społeczeństwie. Jest ona doskonałym źródłem wiedzy, przybliża poszukiwania badawcze i zatroskanie o człowieczeństwo św. Jana Pawła II. Dla mnie osobiście stała się zachętą do dalszych poszukiwań i zgłębiania nauczania papieskiego, gdyż treści w niej prezentowane są nietuzinkowe, a co więcej, zapraszają do myślenia i poszukiwania rozwiązania problemów nurtujących współczesnego człowieka.

Magdalena Bednarczyk*

* Mgr Magdalena Bednarczyk jest doktorantką w Wydziale Nauk Pedagogicznych Uniwersytetu Mikołaja Kopernika w Toruniu. 